\title{
Immunohistochemical and Biochemical Analysis of the Development of the Noradrenaline- and Adrenaline-Storing Cells in the Adrenal Medulla of the Rat and Pig
}

\author{
A. A. J. Verhofstad ${ }^{1}$, R. E. Coupland ${ }^{2}$ and B. Colenbrander ${ }^{3}$ \\ Department of Pathology ${ }^{1}$, University of Nijmegen, The Netherlands; Department of Human Morphology ${ }^{2}$, University of \\ Nottingham, United Kingdom; and Department of Functional Morphology ${ }^{3}$, State University of Utrecht, The Netherlands
}

Summary. The development of the noradrenaline (NA)- and adrenaline (A)-storing cells was examined in the adrenal gland of pre- and postnatal rats and pigs. Cryostat sections were immunostained with antibodies to NA and A. Amine levels were estimated in homogenates of adrenals by ion-pair reversed-phase liquid chromatography with electrochemical detection.

1. In adult animals separate NA- and A-storing cells were found. In the rat $A$-cells comprised about $80 \%$ of the parenchyma of the adrenal medulla. NA-cells, the remaining $20 \%$, were randomly arranged in clusters. In the pig, in contrast, the A- and NA-storing cells were equally distributed, with spherical clusters of NA-cells were surrounded by A-cells.

2. In the earliest developmental stages examined (16th day of gestation in the rat, and 42nd day in the pig) the adrenals only contained NA-immunoreactive cells. In the rat separate $\mathrm{NA}$ - and A-storing cells were first noticed 2 or 3 days after birth, whereas in the pig separated cells were already present at the 56th prenatal day (full term at 114th day).

3. In both rat and pig adrenals dopamine (DA), NA and $A$ increased in amount rapidly during development. In the rat this change mainly took place after birth (an increase of 13 times from the 17 th day of gestation, and a 100 -fold increase from birth to adult age). In porcine adrenal increase of the total amount of amines mainly occurred before birth (200 times between the 42nd day of gestation and birth, whereas only 10 times after birth).

4. In both species DA-levels remained low during preand postnatal development. On the contrary, the relative concentrations of NA decreased while that of $A$ increased correspondingly. Again, species differences were noticed: in the rat $\mathrm{NA}$ decreased from $90 \%$ (17th day of gestation) via $35 \%$ (just before birth) to $20 \%$ at adult age, while the porcine adrenal showed a more gradual decrease, i.e., from $90 \%$ (42nd day of gestation) to $70 \%$ (birth) ending up with $50 \%$ in the adult stage.

5. The immunohistochemical and biochemical data indicate that, in rat adrenal medulla three phases of development can be distinguished. First, up to the 18th day of gestation, medullary cells synthesize and store only NA. Second, from the 18 th day to 2 or 3 days after birth, NA and $A$ are synthesized and stored in a single cell type ("mixed cell type"), and third, NA and A are localized in separate cell types. It remains to be proved whether similar events also occur in the porcine adrenal.

6. Decapitation in pig foetuses (foetal hypophysectomy) at the 42nd, 56th and 92nd day of gestation was found to cause atrophy of the cortex, a strong reduction in the number of A-immunoreactive cells and a marked decrease in the relative concentration of $A$. On the contrary, foetal decapitation affected neither the number of NA-immunoreactive cells nor the total amount of amines contained in the adrenal. These observations indicate a functional relationship between the foetal adrenal cortex and medulla.

The adrenal medulla of adult mammals is composed mainly of two endocrine cell types, i.e., cells synthesizing, storing and releasing noradrenaline (NA) and adrenaline (A). This generally accepted view is based on several histochemical, electron microscopical as well as biochemical studies (e.g., BÄNDER, 1950; ERÄNKÖ, 1952, 1960; HILLARP and HÖKFELT, 1953; COUPLAND, 1971; see also BöcK, 1982). However, among mammals a great variety of species-specific differences in the number and distribution of the NAand A-storing cells as well as the relative concentrations of NA and $\mathrm{A}$ in the adrenal have been described (HÖKFELT, 1951; SHEPHERD and WEST, 1951; ERÄN. KÖ, 1955; PAlKama, 1962; SMOlliCh, 1967; CoupLAND, 1975).

Recent immunohistochemical procedures developed to identify NA- and A-storing cells are more sensitive and more specific than previously described microscopical techniques, and are based on the appli- 


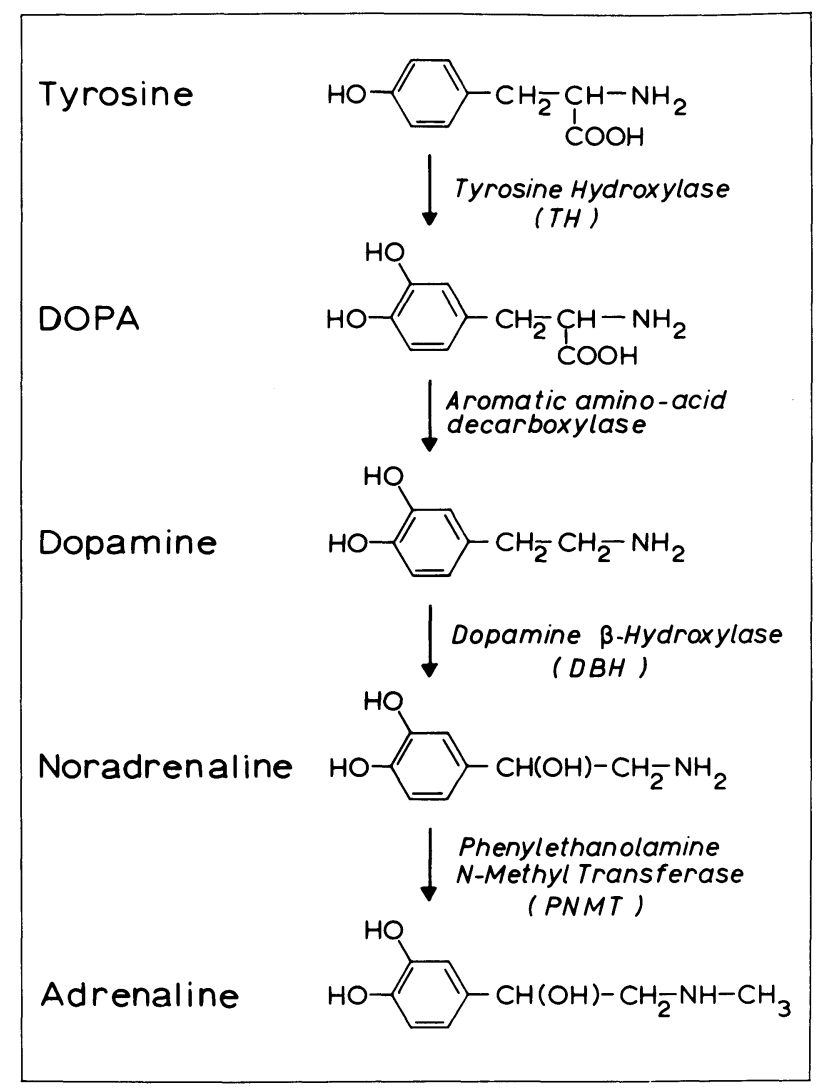

Fig. 1. Biosynthetic pathway of NA and A in the adrenal medulla. Four enzymes are involved: tyrosine hydroxylase $(\mathrm{TH})$, aromatic amino-acid decarboxylase (DOPA decarboxylase, DDC), dopamine- $\beta$-hydroxylase (DBH) and phenylethanolamine $\mathrm{N}$-methyltransferase (PNMT). For references see BlASCHKo (1972), NAGATSU (1973) and STJÄRNE (1972).

cation of antibodies to NA, A and the related biosynthesizing enzymes dopamine $\beta$-hydroxylase (DBH) and phenylethanolamine $\mathrm{N}$-methyltransferase (PNMT) (HÖKFELT et al., 1973; NAGATSU, 1974; VERHOFSTAD et al., 1980; VERHOFSTAD and STEIN. BUSCH, 1986). By the use of these four antibodies, adrenal medullary cells can now be characterized in terms of their amine-synthesizing capacity and of the amines stored in the cell.

In a previous study these immunohistochemical procedures were combined with biochemical techniques to examine the pre- and postnatal development of the rat adrenal medulla (VERHOFSTAD et al., 1985). This approach yielded detailed information on the ratio of the NA- and A-storing cells as well as the absolute and relative concentrations of NA and A. These findings indicate that, in the rat adrenal medul- la, a particular developmental pattern of the parenchymal (chromaffin) cells exists. In order to determine whether a similar pattern occurs in other mammalian species, pig adrenal medulla was selected for examination in this study.

This paper deals with the first results obtained in the pig and compares them with findings from the rat. In addition, since A-synthesis seems to be controlled by corticosteroids, the effect of foetal decapitation ("hypophysectomy" in the foetus) on the development of NA- and A-storing cells as well as NA- and Acontent of the pig adrenal gland is reported.

\section{MATERIALS AND METHODS}

Adrenals were collected from Wistar rats (random breed population, $\mathrm{CpU}$ : WU) and pigs (Dutch Landrace breed) under sodium pentobarbital or azaperone anaesthesia, respectively. Rat tissues were taken at daily intervals from the 16th day of gestation until the 7th postnatal day, at the 14th postnatal day and 2-3 months after birth ("adults"). The age of the rat foetuses was determined by examining vaginal smears of females caged overnight with males. If spermatozoa were found at 9 a.m. the following morning, this day was called the first day of gestation or prenatal period. The day of delivery (on the 22nd day following fertilization) was indicated as the 1st postnatal day.

Pig adrenals were collected at the 42nd, 56th, 92nd and 114th days of gestation (the full term being about day 114 of gestation), at the 20th postnatal day and from adults. Adrenal glands were also collected at the 56th and 92nd days of gestation from pig foetuses which had been previously decapitated at day 42 by the procedure described by STRYKER and DzIUK (1975). Intact foetuses from the same litter served as controls.

\section{Immunohistochemical techniques}

A detailed description of the immunohistochemical procedure employed has been described elsewhere (VERHOFSTAD et al., 1979; VERHOFSTAD et al., 1985; VERHOFSTAD and STEINBUSCH, 1986). In brief, adrenal glands of rat foetuses and postnatal pigs were fixed by immersion for $6-8 \mathrm{~h}$ at $4^{\circ} \mathrm{C}$ with $4 \%$ paraformaldehyde in $0.1 \mathrm{M}$ phosphate buffer, pH 7.2 (PEASE, 1962). Adrenals of postnatal rats and foetal pigs were fixed by perfusion via the left ventricle of the heart, dissected out, and postfixed for $2 \mathrm{~h}$ at $4^{\circ} \mathrm{C}$ in the same fixative. All tissues were then rinsed in $0.1 \mathrm{M}$ phosphate buffer, $\mathrm{pH} 7.2$, containing $5 \%$ sucrose $(18 \mathrm{~h}$ at 
$4^{\circ} \mathrm{C}$ ), frozen in isopentane cooled by liquid nitrogen and cut on a cryostat (thickness $7 \mu \mathrm{m}$ ). The sections were then stained overnight at $4^{\circ} \mathrm{C}$ by the indirect immunofluorescence procedure of CoONS and collaborators using (1958) antibodies to NA $(1: 1000)$ or A ( 1 : 400). Serum from non-immunized animals served as a control. Details on the preparation and characterization of the antisera to NA and A have been reported previously (VERHOFSTAD et al., 1980; VERHOFSTAD and STEINBUSCH, 1986).

A Zeiss Universal microscope equipped for fluorescence with incident illumination and photomicrography was used. Photographs were taken with Kodak Tri-X film.

\section{Biochemical assay}

Adrenals were rapidly dissected, frozen in liquid nitrogen and stored at $-70^{\circ} \mathrm{C}$ prior to assaying. Homogenates were made and the concentrations of dopamine (DA), NA and A were determined by ionpair reversed-phase liquid chromatography with electrochemical detection as described elsewhere in more detail (Michaud et al., 1981; VERHOFSTAD et al., 1985; TOMLINSON et al., 1987).

\section{RESULTS}

\section{Immunohistochemical observations}

The following findings were obtained by careful examination of sets of two adjacent sections, the one stained with the NA-antiserum, and the other with the A-antiserum. Special emphasis was given to the presence and distribution of NA- and A-storing cells applying the criteria indicated in Table 1.

In the adrenal medulla of the adult rat and pig separate NA- and A-storing cells were found. In the rat the NA-storing cells were arranged in smaller or larger clusters, apparently distributed randomly. In the porcine adrenal gland, on the other hand, NAstoring cells formed spherical clusters surrounded by rims of A-storing cells. The relative amount of NA-storing cells also differed between the species. Thus, a semi-quantitative estimate in the rat indicated that NA-storing cells comprised about $20 \%$ of the total number of parenchymal (chromaffin) cells, whereas in the pig, a higher ratio, about $50 \%$, was given.

In both species only NA-storing cells could be found in the adrenal of the earliest developmental stage examined, i.e., the 16th day of gestation in the rat and 42 nd prenatal day in the pig. In the rat the NA-immunoreactive cells were located on the medial
Table 1. Immunoreactivity of parenchymal (chromaffin) cells in the adrenal medulla of adult rats and pigs

\begin{tabular}{lcc}
\hline & NA-storing cells & A-storing cells \\
\hline Immunoreactivity & ++ & + \\
to NA & - & ++ \\
Immunoreactivity & - & + \\
to A & & + \\
\hline
\end{tabular}

++ : strong reaction, $+:$ moderate reaction, $-:$ no reaction

side of the gland, close to and in some sections continuous with the clusters of NA-immunoreactive cells of the medullary anlage (blastema; Fig. 2A, B). In contrast, in the pig, ingrowing NA-immunoreactive cells were observed over the entire surface of the adrenal gland (Fig. 4A, B).

In the rat adrenal separate NA- and A-storing cells were first observed 2 or 3 days after birth (cf. Fig. 3A, $\mathrm{B}$ ), whereas in the pig separate cells were already recognizable at the 56th day of gestation (cf. Fig. 4C, D).

In the rat A-immunoreactive cells, only present inside the adrenal gland, were first noticed at day 18 of gestation. From this stage until 2 or 3 days after birth all medullary cells were immunoreactive both to NA and A (Fig. 2C-F), and separate NA- and A-storing cells were not recognizable. In other words, there was only the "mixed cell type" (see Discussion).

As compared with controls of the same age, pig foetuses sacrificed at the 56th or 92nd prenatal day and previously decapitated at the 42 nd day of gestation, showed a strong reduction in the number of A-immunoreactive cells in the adrenal medulla, in addition to atrophy of the adrenal cortex. However, the number of NA-storing cells did not seem to be reduced (Fig. 4C-F).

\section{Biochemical findings}

In all pre- and postnatal stages examined, DA, NA and $A$ could be demonstrated in rat as well as pig adrenals (Tables 2-5).

Although in the rat, NA was the predominant amine on the 16th till the 19th day of gestation, there was a decrease in the relative cocentration of NAfrom $90 \%$ on the 17 th day to $20 \%$ at the adult age. In contrast, the relative concentrations of $\mathrm{A}$ increased rapidly from $3 \%$ at day 17 to $40 \%$ on day 19 and $65 \%$ just before birth (21st prenatal day), increasing further to $77 \%$ two weeks after birth and to $80 \%$ at the adult age. DA comprised $5 \%$ of the total amount of 

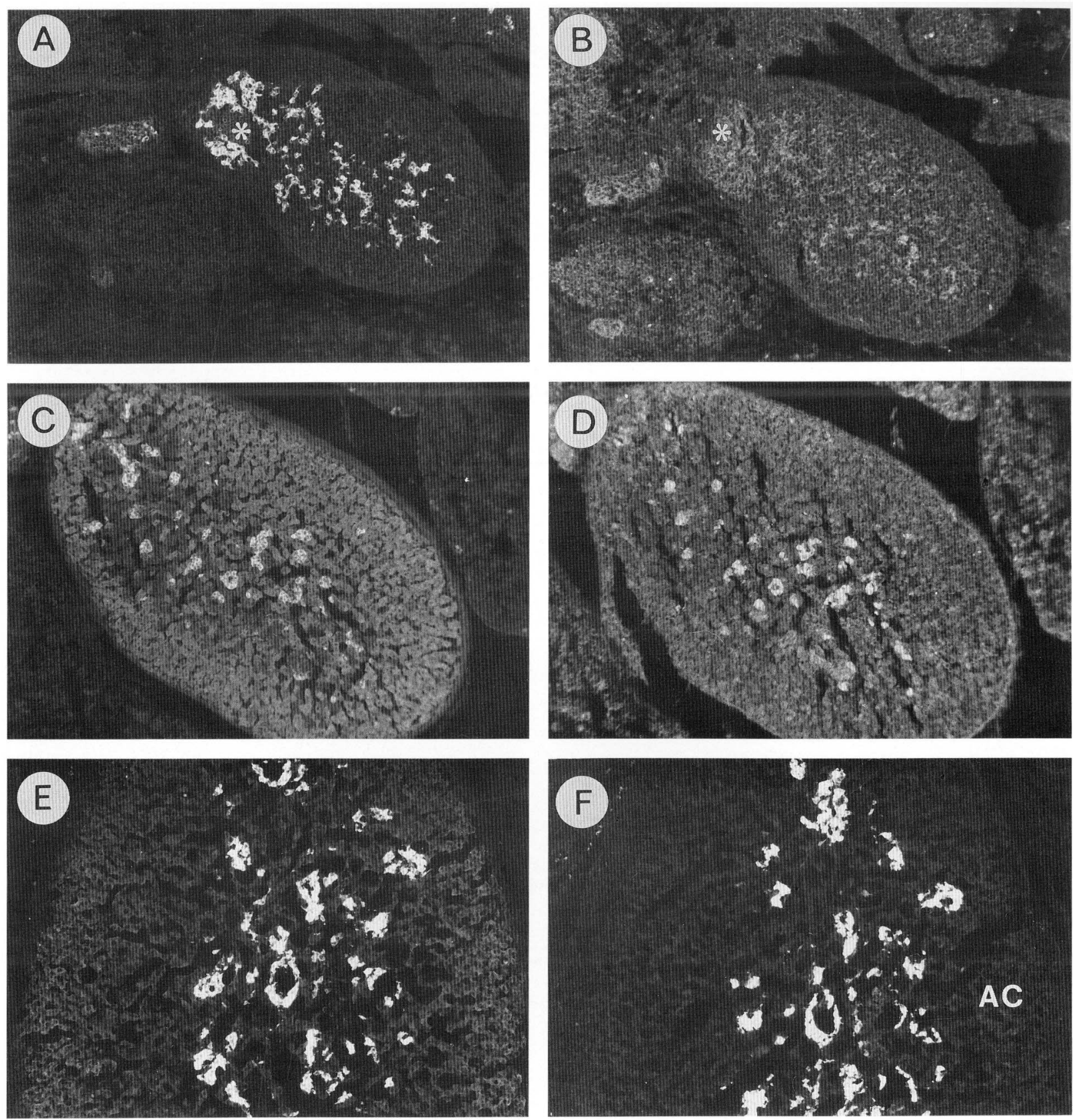

Fig. 2 A-F. Immunofluorescence photomicrographs of rat adrenal gland, 17th (A, B), 19th $(\mathbf{C}, \mathbf{D})$ and 21 st $(\mathbf{E}$, F) day of gestation. Consecutive, transverse sections stained with antisera to NA $(\mathbf{A}, \mathbf{C}, \mathbf{E})$ or A $(\mathbf{B}, \mathbf{D}, \mathbf{F})$. On the 17th day of gestation NA-immunoreactive cells are present in the medullary blastema (asterisk) and in the adrenal gland (A); A-immunoreactivity is not detectable (B). At days $19(\mathbf{C}, \mathbf{D})$ and $21(\mathbf{E}, \mathbf{F})$ in the adrenal gland NA- and A-immunoreactive cells show an essentially identical distribution ("mixed" cell type). $A C$ adrenal cortex. $\times 100$

Fig. $3 \mathrm{~A}$ and B. Immunofluorescence photomicrographs of rat adrenal gland, 14 days after birth. Consecutive, transverse sections stained with antisera to NA (A) or A (B). Note the presence of separate NA- (marked NA) and A-storing cells in the adrenal medulla. AC adrenal cortex. $\times 200$ 
catecholamines at the 17 th prenatal day. During further development DA levels remained low, in adults being less than $1 \%$ (Table 3 ).

The total amount of DA, NA and A increased rapidly from $100 \mathrm{pmol} /$ pair of adrenals on the $17 \mathrm{th}$ prenatal day to $1300 \mathrm{pmol} /$ pair at day 21 (just before birth). After birth a further increase took place, in adults reaching levels which were approximatively 1200 times the levels present at the 17th day of gestation and 100 -fold the amounts found at birth (Table 2).

The pig adrenal gland also showed an increase in the relative concentration of $\mathrm{A}$ and a decrease in the proportion of NA, but these changes were more gradual than in the rat. Thus, on the 42 nd prenatal day A comprised $10 \%$ of the total amount of the catecholamines, rising to $30 \%$ at birth and to $50 \%$ in the adult animals. At the same time the relative concentrations of NA decreased from $90 \%$ at prenatal day 42 to $70 \%$ at birth and $50 \%$ in adults. In none of the developmental stages did the relative concentrations of DA exceed $2-3 \%$, being $1-2 \%$ in the adult adrenal (Table 5).

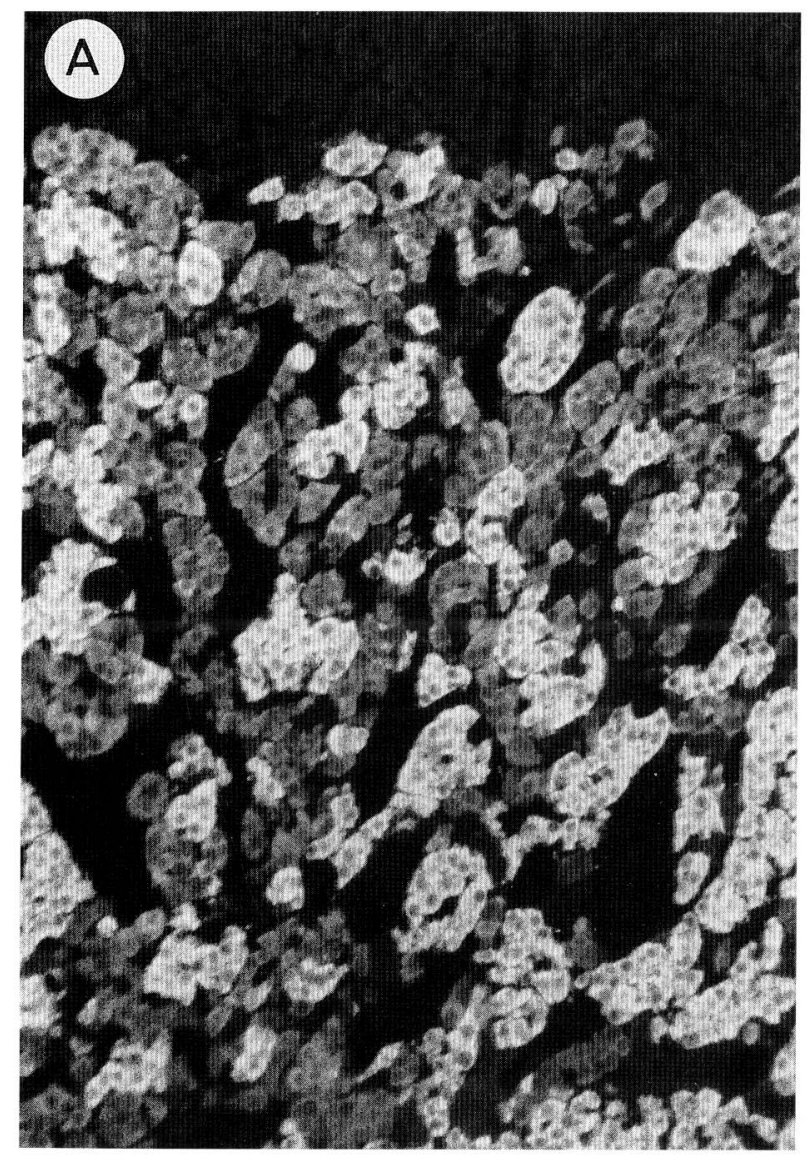

During development in the pig adrenal gland the total amount of catecholamines increased from 11 $\mathrm{nmol} /$ pair of adrenals to $2200 \mathrm{nmol} /$ pair at birth, an increase of approximately 200 times. After birth the total content increased 10 -fold to $21.10^{3} \mathrm{nmol} /$ pair in the adult stage, i.e., about 2000 times the level estimated at day 42 of gestation (Table 4).

Foetal decapitation of pigs at the 42nd day of gestation did not seem to influence the increase in the total amount of catecholamines normally taking place during development (Table 6). However, as compared with the controls of the same age, the relative concentration of $\mathrm{A}$ did not rise and even tended to decline, whereas the proportion of NA increased (see Table 5 and 7). The relative concentration of DA was not affected by foetal decapitation (Table 7).

\section{DISCUSSION}

Immunohistochemical procedures are at present widely used in the study of the cellular localization of the

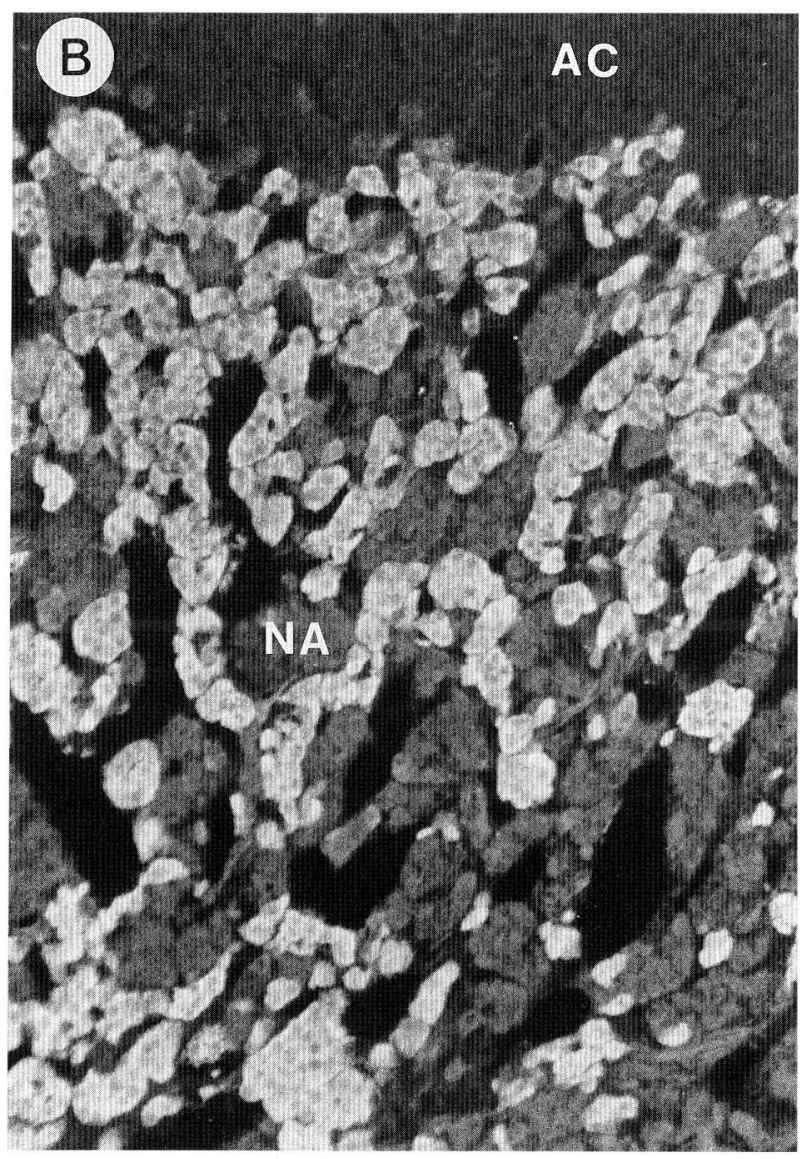

Fig. 3. Legend on the opposite page. 
active principles of endocrine cells, neurons and paraneurons (see e.g., POLAK and BlOOM, 1985; FujiTA et al., 1988). In particular, in the adrenal medulla, the amine-synthesizing and amine-storing capacities of the parenchymal (chromaffin) cells can be identified by antibodies to NA and A (VERHOFSTAD et al., 1980; VERHOFSTAD and JONSSON, 1983; VERHOFSTAD et al., 1985 ; LlOYd et al., 1986; LLOYD, 1988). However, other
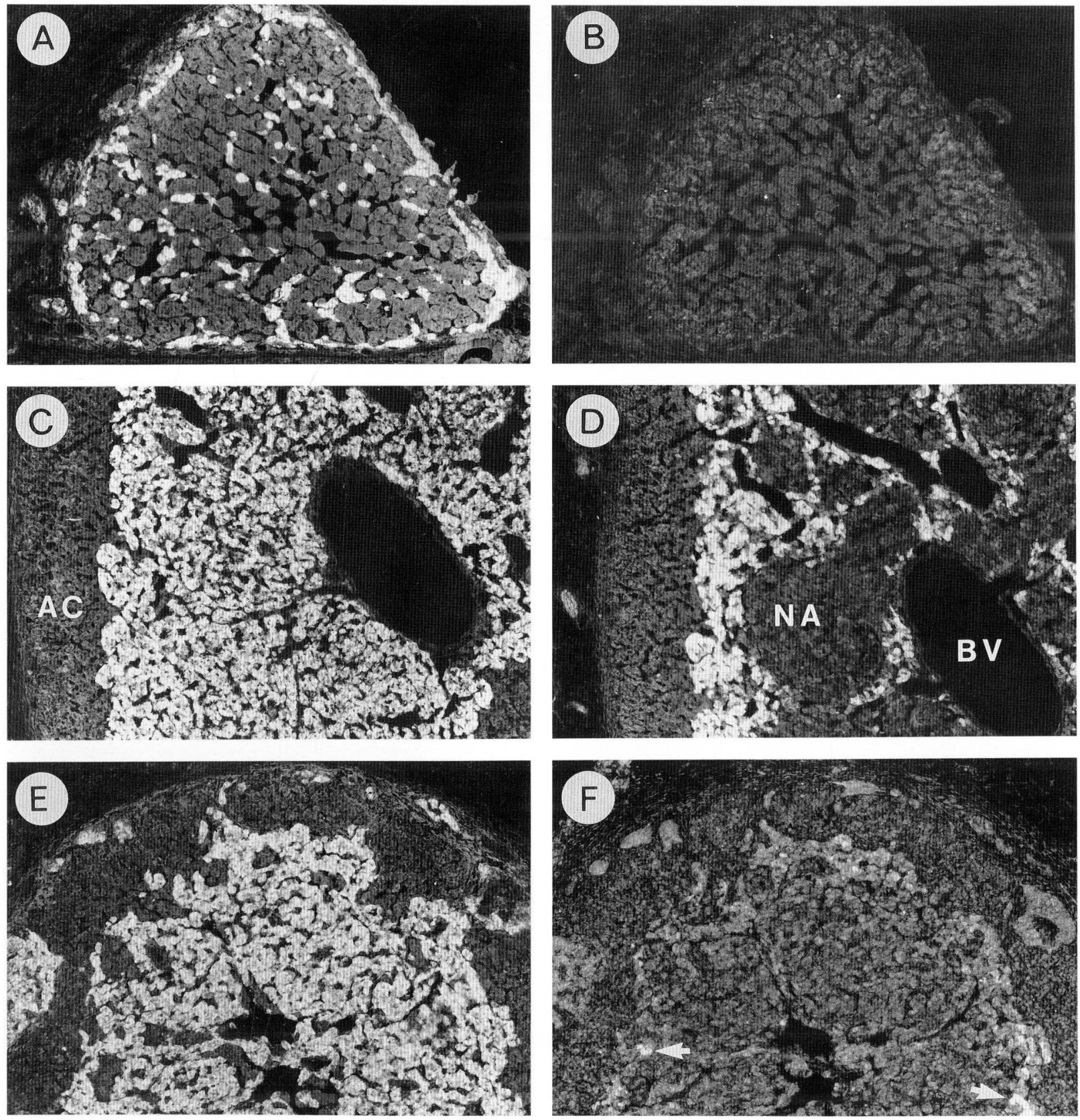

Fig. 4 A-F. Immunofluorescence photomicrographs of pig adrenal gland, 42nd (A, B) and 92nd (C-F) day of gestation. Consecutive, transverse sections stained with antisera to NA (A, C, E) or A (B, D, F). E and F from animals decapitated at day 42 of gestation. Note on the 42 nd day islets of medullary cells only immunoreactive to NA (A, B). Following undisturbed pregnancy, by day 92 separate NA-storing (only immunoreactive to NA) $(N A)$ and A-storing cells are present $(\mathbf{C}, \mathbf{D})$. Decapitated animals of the same age show very few Aimmunoreactive cells (arrows). $A C$ adrenal cortex, $B V$ blood vessel. $\times 100$ 
methods not based on the antigen-antibody reaction, are still needed to exclude unexpected, unwanted cross-reactivity and, e.g., to obtain quantitative data. Therefore, in the present as well as previous study (VERHOFSTAD et al., 1985) on the development of the adrenal medulla, both immunohistochemical and bio- chemical techniques were applied. By this approach it could be demonstrated that, in the rat, the first appearance of the A-immunoreactive cells corresponds quite well with the rise of A-levels as estimated biochemically. In addition, in the adrenals of decapitated pig foetuses, the reduction of the number

Table 2. Contents of DA, NA and A in the adrenal glands of the rat ( $\mathrm{pmol} / \mathrm{pair}$ )

\begin{tabular}{|c|c|c|c|c|c|}
\hline & \multicolumn{3}{|c|}{ Prenatal period (days) } & \multicolumn{2}{|c|}{ Postnatal period (days) } \\
\hline & 17 th $(n=32)$ & 19th $(\mathrm{n}=36)$ & $21 \mathrm{st}(\mathrm{n}=38)$ & 14 th $(\mathrm{n}=2)$ & adult $(\mathrm{n}=3)$ \\
\hline DA & $5.8 \pm 0.7$ & $4.0 \pm 2$ & $9.3 \pm 2$ & 90 & $100 \pm 20$ \\
\hline NA & $110 \pm 15$ & $246 \pm 31$ & $421 \pm 44$ & 860 & $29,000 \pm 4,500$ \\
\hline A & $3.9 \pm 0.3$ & $174 \pm 14$ & $850 \pm 78$ & 3,190 & $116,600 \pm 2,600$ \\
\hline Total & $120 \pm 15$ & $424 \pm 34$ & $1,282 \pm 121$ & 4,200 & $145,800 \pm 6,200$ \\
\hline
\end{tabular}

Table 3. Relative concentrations of DA, NA and A in the paired adrenal glands of the rat (percentage of total amount)

\begin{tabular}{lrrrrrr}
\hline & \multicolumn{2}{c}{ Prenatal period (days) } & & \multicolumn{2}{c}{ Postnatal period (days) } \\
\cline { 2 - 3 } & 17 th $(\mathrm{n}=32)$ & 19th $(\mathrm{n}=36)$ & 21st $(\mathrm{n}=38)$ & & 14th $(\mathrm{n}=2)$ & adult $(\mathrm{n}=3)$ \\
\hline DA & $4.9 \pm 0.4$ & $1.1 \pm 0.6$ & $0.8 \pm 0.2$ & & 2.1 & $0.07 \pm 0.01$ \\
NA & $91.7 \pm 1.2$ & $57.8 \pm 3.8$ & $32.8 \pm 0.6$ & & 20.8 & $19.7 \pm 2.4$ \\
A & $3.4 \pm 0.7$ & $41.2 \pm 3.1$ & $66.5 \pm 0.5$ & & 77.1 & $80.6 \pm 2.3$ \\
\hline
\end{tabular}

Table 4. Contents of DA, NA and A in the adrenal glands of the pig during development (nmol/pair)

\begin{tabular}{lccccccc}
\hline & \multicolumn{2}{l}{ Prenatal period (days) } & & \multicolumn{2}{c}{ Postnatal period (days) } \\
\cline { 2 - 4 } & $42 \mathrm{nd}(\mathrm{n}=8)$ & 56 th $(\mathrm{n}=6)$ & 92nd $(\mathrm{n}=3)$ & 114 th $(\mathrm{n}=6)$ & & 20 th $(\mathrm{n}=4)$ & adult $(\mathrm{n}=1)$ \\
\hline DA & $0.09 \pm 0.02$ & $2.0 \pm 0.8$ & $39 \pm 21$ & N.D. & & $118 \pm 44$ & 316 \\
NA & $9.4 \pm 2.6$ & $120 \pm 36$ & $1,007 \pm 362$ & $1,656 \pm 795$ & & $8,422 \pm 3,990$ & 10,642 \\
A & $1.4 \pm 0.5$ & $12.6 \pm 5.2$ & $431 \pm 142$ & $565 \pm 185$ & & $6,201 \pm 2,844$ & 10,385 \\
Total & $10.9 \pm 3.0$ & $135 \pm 41$ & $1,477 \pm 444$ & $2,221 \pm 963$ & & $14,742 \pm 6,863$ & 21,344 \\
\hline
\end{tabular}

N.D.: not done

Table 5. Relative concentrations of DA, NA and A in the paired adrenal glands of the pig (percentage of total amount)

\begin{tabular}{|c|c|c|c|c|c|c|}
\hline & \multicolumn{4}{|c|}{ Prenatal period (days) } & \multicolumn{2}{|c|}{ Postnatal period (days) } \\
\hline & $42 \mathrm{nd}(\mathrm{n}=8)$ & 56 th $(n=6)$ & 92 nd $(n=3)$ & 114 th $(n=6)$ & 20 th $(\mathrm{n}=4)$ & adult $(n=1)$ \\
\hline DA & $0.8 \pm 0.2$ & $1.5 \pm 0.4$ & $2.5 \pm 0.9$ & N.D. & $0.8 \pm 0.1$ & 1.4 \\
\hline NA & $86.3 \pm 4.7$ & $89.1 \pm 1.7$ & $67.4 \pm 6.8$ & $72.0 \pm 7.6$ & $57.0 \pm 1.9$ & 49.8 \\
\hline A & $12.8 \pm 4.6$ & $9.2 \pm 1.9$ & $29.9 \pm 7.6$ & $27.9 \pm 7.6$ & $42.1 \pm 2.0$ & 48.6 \\
\hline
\end{tabular}

N.D.: not done 
Table 6. Contents of DA, NA and A in the adrenal glands of the pig (nmol/pair) in controls $(\mathrm{C})$ and in animals decapitated (D) at day 42 of gestation

\begin{tabular}{|c|c|c|c|c|}
\hline & \multicolumn{2}{|c|}{56 th day } & \multicolumn{2}{|c|}{ 92nd day } \\
\hline & $C(n=6)$ & $\mathrm{D}(\mathrm{n}=9)$ & $C(n=3)$ & $D(n=2)$ \\
\hline DA & $2 \pm 0.8$ & $2.4 \pm 0.4$ & $39 \pm 21$ & 40 \\
\hline NA & $120 \pm 36$ & $126 \pm 23$ & $1,007 \pm 362$ & 1,705 \\
\hline A & $12.6 \pm 5.2$ & $3.6 \pm 0.7$ & $431 \pm 142$ & 122 \\
\hline Total & $135 \pm 41$ & $132 \pm 24$ & $1,477 \pm 444$ & 1,868 \\
\hline
\end{tabular}

Table 7. Relative concentrations of DA, NA and A in the paired adrenal glands of the pig (percentage of total amount) in controls (C) and in animals decapitated (D) at the day 42 of gestation

\begin{tabular}{lrrrrr}
\hline & \multicolumn{2}{c}{56 th day } & & \multicolumn{2}{c}{92 92d day } \\
\cline { 2 - 3 } \cline { 6 - 6 } & $\mathrm{C}(\mathrm{n}=6)$ & $\mathrm{D}(\mathrm{n}=9)$ & & $\mathrm{C}(\mathrm{n}=3)$ & $\mathrm{D}(\mathrm{n}=2)$ \\
\hline $\mathrm{DA}$ & $1.5 \pm 0.4$ & $1.8 \pm 0.5$ & & $2.5 \pm 0.9$ & 2.3 \\
$\mathrm{NA}$ & $89.1 \pm 1.7$ & $95.3 \pm 0.7$ & & $67.4 \pm 6.8$ & 93.2 \\
$\mathrm{~A}$ & $9.2 \pm 1.9$ & $2.7 \pm 0.5$ & & $29.9 \pm 7.6$ & 4.4 \\
\hline
\end{tabular}

of A-immunoreactive cells was in keeping with the decline in A-levels. However, the combined use of immunohistochemistry and biochemistry also showed that the immunohistochemical procedure utilized is apparently less sensitive than the assay technique. Thus, at the 16th (rat) and 42nd (pig) prenatal days A-immunoreactivity was not recognizable in the adrenal medulla, although low levels of A were already detectable.

In the adrenal medulla of adult rats and pigs separate NA- and A-storing cells could be demonstrated. The distribution as well as the relative proportion of both cell types is in agreement with previous reports (ERÄNKÖ, 1955, 1956; PALKAMA, 1962; SMOLLICH, 1967; COUPLAND, 1975; PALMER, 1978; CouPland et al., 1984; TOMLINSON et al., 1987). Moreover, the relative concentration of NA and A corresponds quite well with earlier data from the literature (ERÄNKÖ, 1955, 1956; Coupland, 1975; Coupland et al., 1984; TOMLINSON et al., 1987). The low concentration of DA as well as immunohistochemical results based on the application of antibodies to the synthesizing enzymes tyrosine hydroxylase and DBH (unpublished observations) do not seem to indicate the occurrence of separate DA-storing cells in the rat or pig adrenal medulla.

As discussed in more detail elsewhere (VERHOF STAD et al., 1985), the available immunohistochemi-

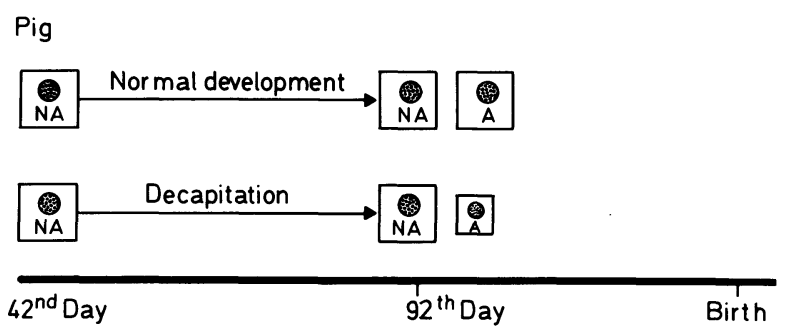

Fig. 5. Diagrammatic presentation of the effect of foetal decapitation ("hypophysectomy") in pigs. Decapitation at day 42 reduces the number of A-storing cells (as well as the relative A concentration) in the adrenal medulla of animals sacrificed at day 92 of gestation.

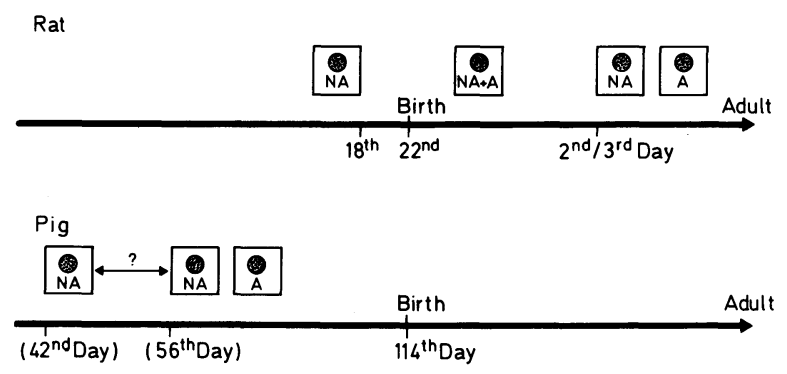

Fig. 6. Developmental phases of the parenchymal (chromaffin) cells in the adrenal medulla of the rat and pig. Note that in the rat separate NA- and A-storing cells first appear after birth, whereas in the pig separate cell types are already present at day 56 of gestation. The data do not exclude the possibility that essentially the same sequence of events exists in the rat and pig. However, to prove this supposition, future studies in the pig should include adrenals taken from animals before day 42 and between the 42 nd and 56th days of gestation.

cal and biochemical data indicate that three phases can be distinguished during the development of the adrenal medulla in the rat (Fig. 6). First, before the 18th day of gestation medullary cells synthesize and store only NA. The capacity to convert NA into A is only achieved during the second phase of development, i.e., from the 18th day of gestation until the 2 nd or 3rd postnatal day. However, during this stage in the adrenals high levels of NA are found. Moreover, at birth, the medullary cells of the rat contain mixtures of storage granules which in adults are encountered in separated NA- and A-storing cells (ELFVIN, 1967; El-Maghraby and LeVER, 1980; Coup. LAND, 1980). Therefore, it seems likely that, peri- 
natally, medullary cells are not able to convert NA into A completely, and probably store and release the remaining NA independently ("mixed" cell type). Separate NA- and A-storing cells first appeared at the 2nd or 3rd postnatal day, marking the beginning of the third developmental phase in rat adrenal medulla.

During the initial stages of development of the porcine adrenal the medullary cells only contain NA. However, in this species separate NA- and A-storing cells already appear long before birth (Fig. 6). Thus, if the three developmental phases also exist in the pig one may expect a "mixed cell type" to be present between the 42nd and 56th day of gestation, but this developmental period has not yet been confirmed. It is thus still uncertain whether the model presented for the developing rat adrenal medulla also holds for the porcine adrenal. At any rate, from the present observations one may infer different responses to (patho) physiological or pharmacological stimuli applied to adrenals of the two animal species during the late foetal period.

The results achieved from the decapitation experiments in the pig indicate an intact hypophysealadrenocortical system being a prerequisite for the conversion of NA into $\mathrm{A}$ in the foetal adrenal medulla. Apparently the lack of corticosteroids does not affect the amount of NA synthesized. The findings indicate the existence of a functional relationship between the foetal adrenal cortex and medulla of the pig comparable to the situation previously suggested for the rat adrenal (VERHOFSTAD et al., 1979, 1985). In the rat the first appearance of separate NA- and A-storing cells seems to coincide with the time when the neural control of the adrenal medullary cells is established (SLOTKIN et al., 1980; SEIDLER and SLOT KIN, 1985; VON DALNOK and MENSSEN, 1986). If, as was suggested previously (VERHOFSTAD et al., 1985), neurotrophic factors are involved in this process, one can expect that the innervation of the pig adrenal medulla is already operational long before birth.

\section{REFERENCES}

BäNDER, A.: Über zwei verschiedene chromaffine Zelltypen im Nebennierenmark und ihre Beziehung zum Adrenalin und Arterenolgehalt. Anat. Anz. 97: 172-176 (1950).

BLASCHKo, H.: Catecholamines 1922-1971. In: (ed. by) H. BlaschKo and E. Muscholl: Catecholamines (Handbook of Experimental Pharmacology. Vol. 33). Springer, Berlin, 1972 (p. 1-5).
Böck, P.: The paraganglia. In: (ed. by) A. OKSCHE and L. VOllRATH: Handbuch der mikroskopischen Anatomie des Menschen, VI/8. Springer, Berlin, 1982.

Coons, A. H.: Fluorescent antibody method. In: (ed. by) J. F. DANIELli: General cytochemical methods. Academic Press, New York 1958 (p. 399-422).

Coupland, R. E.: Observations on the form and size distribution of chromaffin granules and on the identity of adrenaline- and noradrenaline-storing cells in vertebrates and man. Mem. Soc. Endocrinol. 19: 611-633 (1971).

: The adrenal medulla. In: (ed. by) F. BECK and J. B. Lloyd: The cell in medical science, Vol 3. Academic Press, London, 1975 (p. 193-242).

-: The development and fate of catecholamine secreting endocrine cells. In: (ed. by) H. PARVEZ and S. PARVEZ: Biogenic amines in development. Elsevier, Amsterdam, 1980 (p. 3-28).

Coupland, R. E., A. Tomlinson, J. Crowe and D. N. BRINDLEY: Effects of hypophysectomy and metyrapone on the catecholamine content and volumes of adrenaline- and noradrenaline-storing cells in the rat adrenal medulla. J. Endocrinol. 101: 345-352 (1984).

DalnoK, G. K. von and H. D. Menssen: A quantitative electron microscopic study of the effect of glucocorticoids in vivo on the early postnatal differentiation of paraneuronal cells in the carotid body and the adrenal medulla of the rat. Anat. Embryol. 174: 307-319 (1986).

Elfvin, L. G.: The development of the secretory granules in the rat adrenal medulla. J. Ultrastr. Res. 17: 4562 (1967).

El-Maghraby, M. and J. D. Lever: Typification and differentiation of medullary cells in the developing rat adrenal. A histochemical and electron microscopic study. J. Anat. 131: 103-120 (1980).

ERÄNкö, 0.: On the histochemistry of the adrenal medulla of the rat, with special reference to acid phosphatase. Acta Anat., Suppl. 17: 1 Ad Vol. X VI (1952).

- : Fluorescing islets, adrenaline and noradrenaline in the adrenal medulla of some common laboratory animals. Ann. Med. Exp. Biol. Fenn. 33: 278-290 (1955).

- Distribution d'adrénaline et de noradrénaline dans la médullaire surrénale. Sem. Hôp. Paris 32: 48-51 (1956).

- Cell types of the adrenal medulla. In: (ed. by) G. E. W. Westenholme and W. O'Connor: Ciba Foundation Symposium on adrenergic mechanisms. Churchill, London, 1960 (p. 103-108).

Fujita, T., T. Kanno and S. Kobayashi: The paraneuron. Springer, Tokyo-Berlin, 1988.

HillarP, N. A. and B. HöKFElt: Evidence of adrenaline and noradrenaline in separate adrenal medullary cells. Acta Physiol. Scand. 30: 55-58 (1953).

HökfELT, B.: Noradrenaline and adrenaline in mammalian tissues. Distribution under normal and pathological conditions with special reference to the endocrine system. Acta Physiol. Scand. 25, Suppl. 92 (1951).

Hökfelt, T., K. FuXe, M. Goldstein and T. H. JoH: 
Immunohistochemical localization of three catecholamine synthesizing enzymes: aspects on methodology. Histochemie 33: 231-254 (1973).

LLOYD, R. V.: Immunohistochemical localization of catecholamines, catecholamine synthesizing enzymes, and chromogranins in neuroendocrine cells and tumors. In: (ed. by) R. A. DeLellis: Advances in immunohistochemistry. Raven, New York, 1988 (p. 317-339).

Lloyd, R. V., J. C. Sisson, B. Shapiro and A. A. J. VERHOFSTAD : Immunohistochemical localization of epinephrine, norepinephrine, catecholamine-synthesizing enzymes, and chromogranin in neuroendocrine cells and tumors. Amer. J. Pathol. 125: 45-54 (1986).

MichaUd, R. L., M. J. BANnon and R. H. Roth: The use of C8-octyl columns for the analysis of catecholamines by ion-pair reversed-phase liquid chromatography with ampherometric detection. J. Chromat. 225: 335-345 (1981).

NAGATSU, I. : Localization of dopamine $\beta$-hydroxylase in bovine adrenal gland and rat sciatic nerves by the improved enzyme-immunohistochemical and enzymeimmunofluorescent methods. Acta Histochem. Cytochem. 7: 147-157 (1974).

NaGatsu, T.: Biochemistry of catecholamines. The biochemical method. University Park Press, Baltimore, 1973.

Palkama, A.: Distribution of adrenaline, noradrenaline, acid phosphatase, cholinesterases and non-specific esterases in the adrenal medulla of some mammals. A comparative histochemical study. Ann. Med. Exp. Biol. Fenn. 40, Suppl. 3 (1962).

Palmer, E. G.: Certain cytologic features of the porcine adrenal medulla. Amer. J. Vet. Res. 39: 1363-1366 (1978).

Pease, D. C.: Buffered formaldehyde as a killing agent and primary fixative for electron microscopy. Anat. Rec. 142: 342 (1962).

Polak, J. M. and S. R. BLoom: Endocrine tumours. Churchill Livingstone, Edinburgh, 1985.

Seidler, F. J. and T. A. Slotkin: Adrenomedullary function in the neonatal rat: responses to acute hypoxia. J. Physiol. (Lond.) 358: 1-16 (1985).

ShePherd, D. M. and G. B. West: Noradrenaline and the adrenal medulla. Brit. J. Pharmacol. 6: 665-674 (1951).

Slotkin, T. A., P. G. Smith, C. LAU and D. L. Bareis: Functional aspects of development of catecholamine biosynthesis and release in the sympathetic nervous system. In: (ed. by) O. PARVEZ and H. PARvez: Biogenic amines in development. Elsevier, Amsterdam, 1980 (p. 29-48).

Smollich, A.: Lokalization der Adrenalin- und Noradrenalinbildungsstätten im Nebennierenmark einiger Haustierarten. Z. Mikrosk. Anat. Forsch. 77: 73-89 (1967).
STJÄRNe, L.: The synthesis, uptake and storage of catecholamines in the adrenal medulla. The effect of drugs. In: (ed. by) H. BlaschKo and E. Muscholl: Catecholamines (Handbook of Experimental Pharmacology. Vol. 33). Springer, Berlin, 1972 (p. 231-269).

STrYker, J. L. and P. J. Dziuk: Effects of fetal decapitation on fetal development, parturition and lactation in pigs. J. Animal Sci. 40: 282-287 (1975).

Tomlinson, A., J. Durbin and R. E. Coupland: A quantitative analysis of rat adrenal chromaffin tissue: morphometric analysis at tissue and cellular level correlated with catecholamine content. Neuroscience 20: 895-904 (1987).

Verhofstad, A. A. J. and G. Jonsson: Immunohistochemical and neurochemical evidence for the presence of serotonin in the adrenal medulla of the rat. Neuroscience 10: 1443-1453 (1983).

Verhofstad, A. A. J. and H. W. M. Steinbusch: Immunocytochemical localization of intrinsic amines. In: (ed. by) J. M. POLAK and S. VAN NoORdEN: Immunocytochemistry: modern methods and applications. Wright, Bristol, 1986 (p. 284-307).

Verhofstad, A. A. J., T. Hökfelt, M. Goldstein, H. W. M. Steinbusch and H. W. J. Joosten: Appearance of tyrosine hydroxylase, aromatic amino-acid decarboxylase, dopamine $\beta$-hydroxylase and phenylethanolamine $\mathrm{N}$-methyltransferase during the ontogenesis of the adrenal medulla. An immunohistochemical study in the rat. Cell Tiss. Res. 200: 1-13 (1979).

Verhofstad, A. A. J., H. W. M. Steinbusch, B. Penke, J. VARGA and H. W. J. Joosten: Use of antibodies to norepinephrine and epinephrine in immunohistochemistry. In: (ed. by) O. ERÄNKÖ, S. SOINILA and H. PAIVARIN. TA: Histochemistry and cell biology of autonomic neurons, SIF cells and paraneurons (Adv. Biochem. Psychopharmacol. Vol. 25). Raven, New York, 1980 (p. 185193).

Verhofstad, A. A. J., R. E. Coupland, T. R. Parker and M. GoLdstein: Immunohistochemical and biochemical study on the development of the noradrenaline and adrenaline-storing cells of the adrenal medulla of the rat. Cell Tiss. Res. 242: 233-243 (1985).

\author{
Dr. A. A. J. Verhofstad \\ Department of Pathology \\ University of Nijmegen \\ P. O. Box 9101 \\ 6500 HB Nijmegen, The Netherlands
}

